\title{
In Silico Study of Histo-aspartic Protease (HAP) Inhibitor from Indonesian Medicinal Plants: Anti-malarial Discovery
}

\author{
Dinar Mutia Rani, Muhammad Habiburrohman, Yoshinta Debby, Bawon Triatmoko, Ari Satia \\ Nugraha*
}

Drug Utilisation and Discovery Research Group, Faculty of Pharmacy, University of Jember, Jember, Indonesia 68121

*Corresponding author:

E-mail: arisatia@unej.ac.id

\begin{abstract}
Malaria is an infectious disease caused by Plasmodium $s p$ with the highest clinical incidence of $12.07 \%$ in Indonesia. New anti-malaria compounds are needed to replace antimalarial drugs that are already resistant nowadays. One of the efforts to find a new anti-malaria drug is through research on traditional medicinal plants used by Indonesian tribes from the ethnopharmacology database. In silico studies provide saving solutions in the process of computer-aided drug design. Histo-aspartic protease (HAP) is essential for the growth of Plasmodium falciparum and has been validated as an antimalarial drug target. Therefore, molecular docking was used to provide new insights into the development of drugs by targeting HAP protease. There are 238 compounds from 43 medicinal plants used as targeting ligand in this study prepared by Autodock Vina for an automated docking tool. The comprehensive docking protocol was valid showed by the RMSD value of 1,275 A. The result obtained that AM50 (borrasosides A) from Borassus flabellifer was found to have the least affinity score of $-10.1 \mathrm{kcal} / \mathrm{mol}$ higher compared to the native ligand. In conclusion, we are assuming that the mechanism of borrasosides A compound might get involved with HAP. Further protocols are required to prove the HAP inhibition towards Plasmodium falciparum.
\end{abstract}

Keywords: HAP inhibitor, molecular docking, antimalarial, Borassus flabellifer, Borrasosides A

\section{Introduction}

Malaria is an infectious disease caused by Plasmodium sp and is transmitted directly through the sexual stage of the parasite by Anopheles mosquitoes (Petersen et al., 2011; World Health Organization, 2014). In 2015, there were 211 million cases and around 445,000 deaths in the world due to malaria (World Health Organization, 2017). Asian region included Indonesia is classified as a moderate endemic area with $95 \%$ of the region and $99 \%$ of the population at risk characterized by seasonal, intense malaria transmission (Gething et al., 2011). Therefore, the effectiveness of treatment becomes important to reduce morbidity and mortality. However, the treatment management of malaria with prevalent medicines severely associated with the widespread presence of Plasmodium falciparum strains resistant to the most affordable drugs such as mefloquine, qloroquine, and sulfadoxine-pyrimethamine (Guiguemde et al., 1994; Pratiwi et al., 2014; Müller et al., 2003). Inconsequence, new anti-malaria compounds are needed to replace inefficient antimalarial drugs due to resistance. One of the good sources for the new anti-malaria drug is medicinal plants which in Indonesia, the plants were documented and stored as ethnopharmacological database (Lailaty et al., 2016). Indonesia has the second largest biodiversity in the world after

\section{How to cite:}

Rani, D. M., Habiburrohman, M., Debby, Y., Triatmoko, B., \& Nugraha, A. S. (2021). In Silico Study of Histo-aspartic Protease (HAP) inhibitor from indonesian medicinal plants: Anti-malarial discovery . The 3rd International Conference on Life Sciences and Biotechnology. NST Proceedings. pages 17-24. doi: 10.11594/ nstp.2021.0803 
Brazil which is comprised of around 6000 medicinal plants that have been used to treat diseases through generations (Nugraha \& Keller, 2011).

Current conventional protocols in new drug screening and discovery were costly and timeconsuming. The introduction of in silico protocol has led to minimizing the risk of trial and error failure (Suhud et al., 2015). In this study, a total of 238 compounds derived from 43 Indonesian medicinal plants uses in malarial therapy were collected. The mechanism of action of these compounds has not been investigated with certainty, and scientific approaches are needed to find out the mechanism of action (Rollando et al., 2017). Histo-aspartic protease (HAP) is one of the certain enzymes in complex with the crystal structure of inhibitor KNI-10006 found in P. falciparum which causes malaria (Bhaumik et al., 2009). This enzyme involves in the degradation of human hemoglobin to provide nutrients for the development and maturation of Plasmodium (Banerjee et al., 2002), making them potentials targets for novel antimalarial therapy (Ersmark et al., 2006). Therefore, this study aims to determine 238 compounds from 43 medicinal plants with the highest potential as antimalarial through the mechanism of action as the HAP inhibitors.

\section{Material and Methods \\ Materials}

The computer used was Sony series VPCJ228FG on Intel® Core ${ }^{\mathrm{TM}} \mathrm{i} 5-2430 \mathrm{M}$ Processor 2.40 GHz with Windows ${ }^{\circledR} 7$ Home Premium (64-bit). The software installed and used were PyMol for analyzing interaction among ligand with an enzyme, Chem Draw Ultra 12.0 for drawing 2D ligand structure, Chem3D 12.0 for 3D visualization and energy minimize, while ligand, protein preparation, and molecular docking were performed using Autodock tools \& Autodock Vina. The in silico study was conducted through a molecular docking approach to obtain compound hits with the highest affinity toward (4R)-3-[(2S,3S)-3-\{[2,6-dimethylphenoxy)acetyl]amino $\}$-2-hydroxy-4phenylbutanoyl]-N-[1S,2R)-2-hydroxy-2,3-dihydro-1H-inden-1-yl]-5,5-dimethyl-1,3-thiazoli-

dine-4-carboxamide. Furthermore, an enzyme used in this study was Histo-aspartic Protease (HAP) (Figure 1), a target enzyme for catalytic aspartate (PDB, 3FNU) which obtained from the website of Protein Data Bank (PDB) (https://rcsb.org). Compounds for molecular docking were obtained from previously reported medicinal plants in which the plants were used as antimalarial in Indonesia. Scifinder database searching was employed to gain these secondary metabolites (https://scifinder.cas.org.)

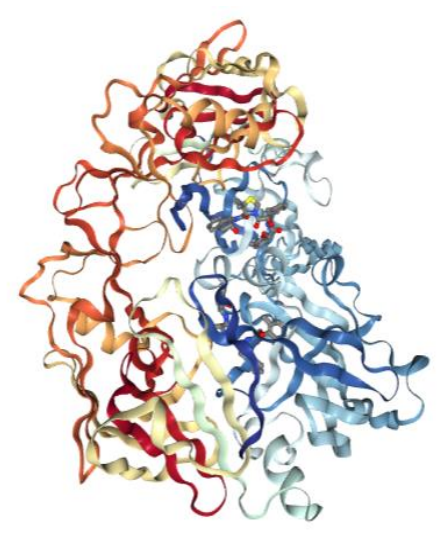

Figure 1. 3D Structure of Histo-aspartic Protease

\section{Ligand and enzyme preparation}

The enzyme was downloaded in a.pdb format, then all the hydrogens molecule is removed. Native ligand removal from the enzyme was done using PyMol, and added hydrogen polar to the enzyme using autodock tools. Ligands were prepared from 238 compounds from 43 Indonesian 
medicinal plants, each ligand is sketched into the two-dimensional structure using ChemDraw2D 12.0 and was then geometric optimized using force field molecular mechanism MM2. This method was used to obtain the most stable structure conformation which structure was then saved in the PDB file extension. All the ligands were formatted in PDBQT files by using auto dock tools.

\section{Griding and molecular docking}

Griding is used to determine the enzyme region for proper molecular docking. Original ligand is used as a reference for the location of ligand docking and was done using autodock tools. Furthermore, on the molecular docking process, ligand and enzyme in.pdbqt format were put in one folder, then added "conf.txt", a text with the extension .txt including file name, and the griding region for ligand attachment. Molecular docking was done using Autodock Vina software.

\section{Visualization}

Ligand results from molecular docking are visualized using PyMol software. Also, PyMol visualized the interaction between the ligand and its enzyme in the form of an affinity score. PyMol's also able to read ligand an enzyme in a variety of file extensions.

\section{Results and Discussion}

Molecular docking is an in silico method to predict the possible activity that occurred between ligands and protein's target. Free energy of binding $(\Delta G)$ and amino acid residues was observed as the docking parameters using PyMol software. Docking resulted from the best 3 compounds based on the free energy binding score (table 1 ). $\Delta \mathrm{G}$ score is related to the affinity score of a ligand. The lower score of $\Delta \mathrm{G}$ indicates the higher score of ligand's affinity which binds to the active site of the enzyme. The lower free energy score in order was ligand AM50, a borrasosides A from Borassus flabellifer, then AM147, a northalifoline from Michelia figo, and AM202, a cassiamin B from Cassia siamea. The final score indicates that those compounds had more smallest affinity score compared to the native ligand with a $\Delta \mathrm{G}$ score of $-9.4 \mathrm{kcal} / \mathrm{mol}$. $\Delta \mathrm{G}$ score shows the bond and inhibitory strength of ligand and enzyme.

Thermodynamically, metabolism reactions in the body happened in exergonic and endergonic. Exergonic brings the free energy for undertaking the reaction under constant temperature and pressure. This reaction-induced free energy of reactor molecules decreases because the energy is released during the reaction (Nelson et al., 2008). Therefore, the product energy is lower than the reagents energy, indicating that the lower energy of molecules, the more spontaneous and stable reaction happened (Nelson et al., 2008). The more stable ligand-protein interaction is reflected by the lower score (minus) (Purnomo, 2011). Therefore, AM50, AM147, and AM202 have antimalarial activity against $P$. falciparum that binds to the HAP through molecular docking. Comparison of scores between compounds can explain whether a compound is potent or not. The smaller a docking result means the protein-ligand complex is more stable so that the compound is more potent.

The docking protocol was also validated by docking the native ligand and compared with the one in crystal form. Therefore, we get the geometrical deviation as Root Mean Square Deviation (RMSD). The RMSD score was obtained from the optimization of conformation at the best position during the redocking process and the way the ligand binds to the protein. The smaller of RMSD score indicates that the expected position of the ligand is getting better because it is getting closer to the standard conformation or comparison (Gaspersz \& Sohilait, 2019). The results of the validation between the ligands obtained an RMSD value of 1,275 A. The RMSD result reported valid if the RMSD parameter assessment obtained is $<2 \AA$ (Thomas, 2004), which indicates that the validated ligands and proteins are appropriate. 
Table 1. Docking Result Toward Histo-aspartic Protease

$\begin{gathered}\text { Code and Compound Structure and Source } \\ \text { name }\end{gathered}$
(Borassus flabellifer)

Borrasosides $A$

AM 202 (Cassia siamea)<smiles>Cc1cc2c(c(O)c1-c1c(C)cc3c(c1O)C(=O)c1c(O)cc(O)cc1C3=O)C(=O)c1cc(O)cc(O)c1C2=O</smiles>

AM 147 (Michelia figo)

$$
\text { Cassiamin B }
$$<smiles>COc1ccc2c(c1)C[C@@H](O)N(C)[C@H]2Cc1ccc(O)c(Oc2ccc(CC3NCCc4cc(OC)c(O)cc43)cc2)c1</smiles>

Northalifoline

Based on the docking result, the best three compounds showed hydrogen bonding interaction. A hydrogen bond is an attraction between molecules or dipoles formed towards two partial charges with opposite polarity. Hydrogen bonds occur when an atom gives the hydrogen covalent 
bond (donor) to the electronegative atom (acceptor). A large number of hydrogen bonds determines the strength of the interaction. So that this ligand is considered to have high stability (Malau \& Azzahra, 2019).

Also, visualization is needed to determine the amino acids that play a role in maintaining the stability of these compounds at their receptors (Purnomo, 2011). Amino acid residues from the 3 highest affinity test ligands were compared with the results of redocking co-crystal ligands to receptors, to assess the interaction between test ligands and co-crystal ligands similarity shown in table 2 and figure 2-5. In case, test ligands had amino acid residues that are similar to co-crystals, it may represent a possibility of similar activity toward test ligand and co-crystal ligands. In the fact, the docking results show that there is only an AM202 compound that has similarity structure toward co-crystal ligand, attach to amino acid residue TRP-39. Furthermore, besides AM202, it shows a relatively low similarity to co-crystal ligands, which explains that there is a tendency for differences in interaction between the test ligands and co-crystal ligands (Barelier et al., 2015). However, the bonding of the compound gives a higher bond strength score than the co-crystal ligand, which doesn't mean that amino acid residue similarity did not provide activity toward the test ligand.

Table 2. Amino acid residues

\begin{tabular}{cllll}
\hline Ligand & HAP ligand & AM 50 & AM 147 & AM 202 \\
\hline Amino & Trp-39 & Leu-243 & His-32 & Trp-39 \\
acid & & Leu-244 & & Ile-130 \\
residues & & Ser-243A & & Asn-37 \\
& & & Ser-35 \\
& & & Leu-128 \\
\hline
\end{tabular}

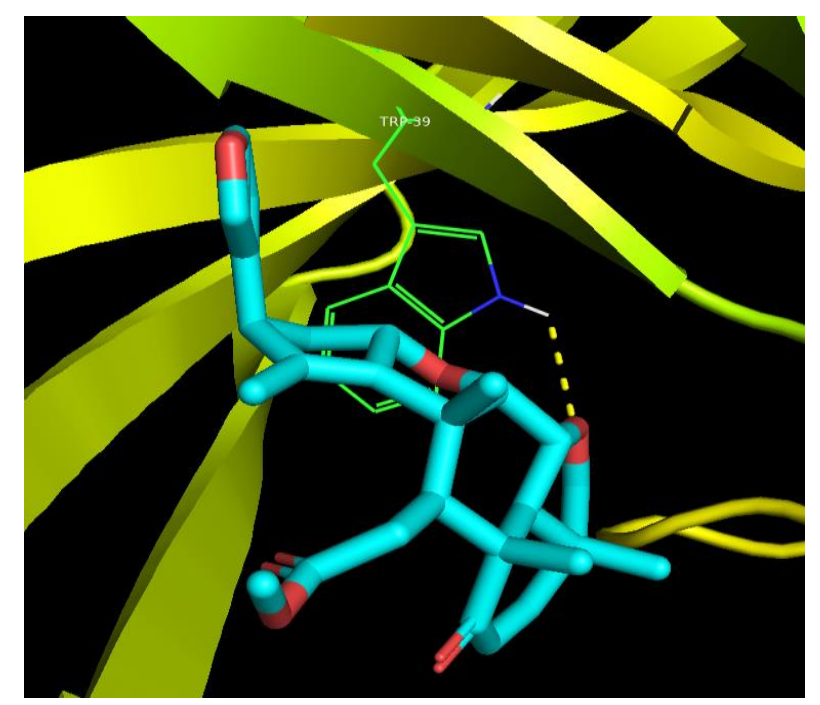

Figure 1. Interaction Visualization HAP Ligand showing hydrogen bonding with Trp-39a 


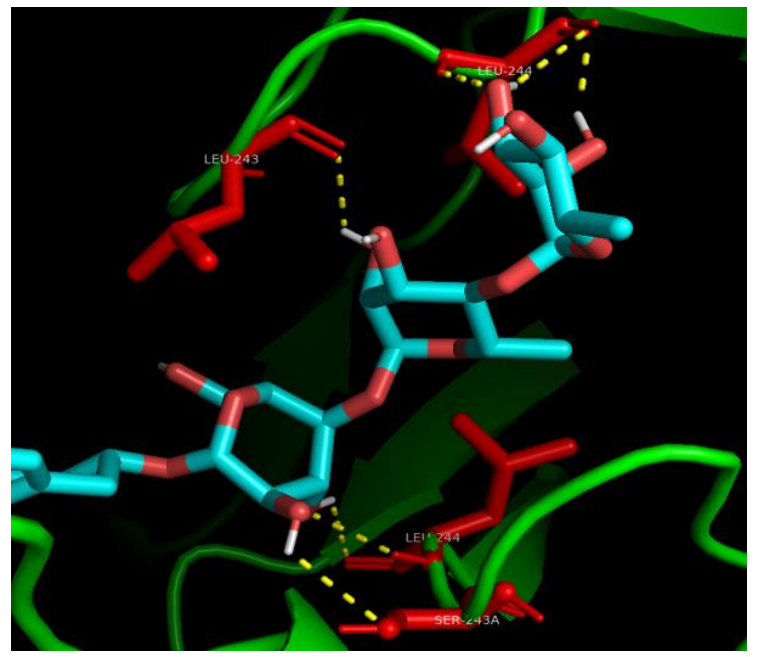

Figure 2. Interaction visualization AM 50 showing hydrogen bonding with Leu-243, Leu-244, Ser-243A

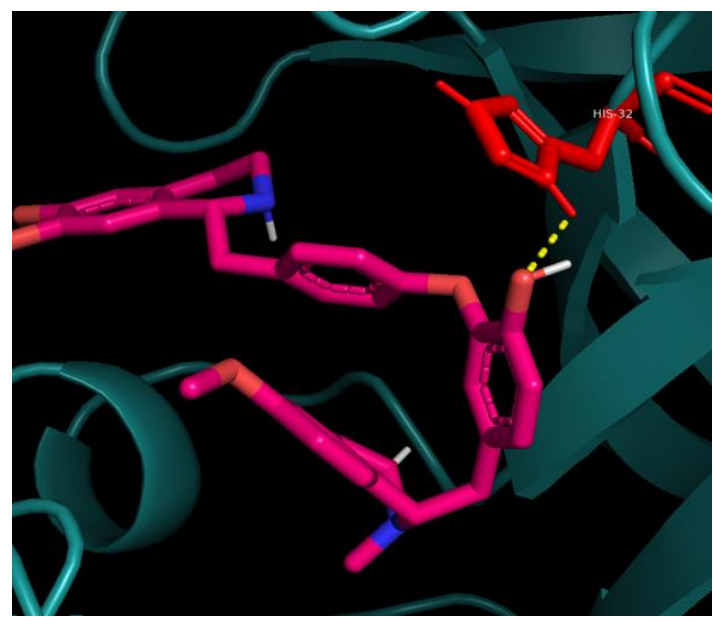

Figure 3. Interaction visualization AM 147 showing hydrogen bonding with His-32

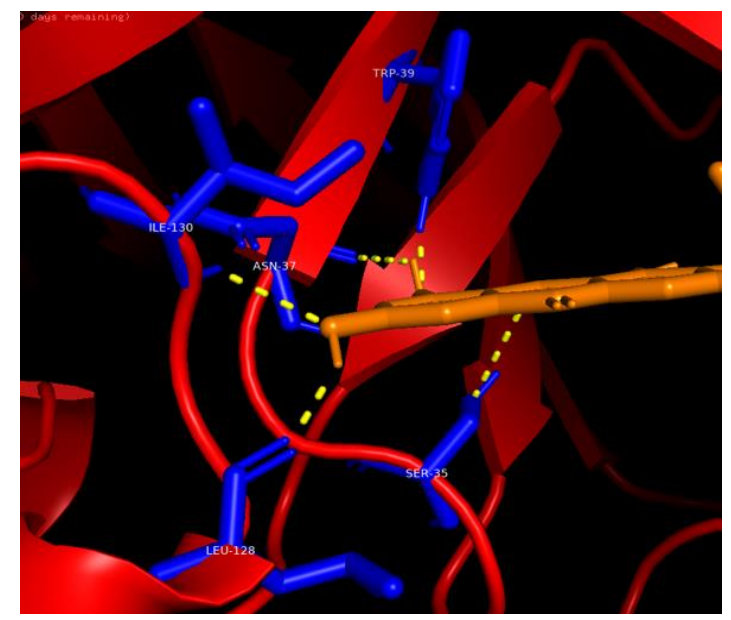

Figure 4. Interaction visualization AM 202 showing hydrogen bonding with Trp-39, Ile-130, Asn-37, Ser35, Leu-12 
Previous research has reported that Borassus flabellifer, Michelia figo, and Cassia siamea possessed a potential activity as an antimalarial agent (Badan Penelitian dan Pengembangan Kesehatan, 2006; Badan Penelitian dan Pengembangan Kesehatan, 1997; Irawanto, 2011). However, the mechanism of action was not yet known. This study revealed the possible mechanism of action of secondary metabolites of the three medicinal plants as antiplasmodial agents. HAP is directly involved in the process of hemoglobin degradation (Coombs et al., 2001). During the parasitic growth phase in the human body, it breaks down large amounts of host hemoglobin in erythrocytes to obtain amino acids to synthesize protein (Kolakovich et al., 1997; Xiao et al., 2007) and also reduces colloidal osmotic pressure in the host cell, thereby preventing premature lysis (Esposito et al., 2008). This degradation process occurs in the parasitic food vacuole. On its prevention, the HAP needs to be inhibited. Molecular docking showed an interesting result where the affinity score of the test ligand has bonding strength to the HAP. Thus, the reaction of hemoglobin degradation on retrofit will be inhibited, so that the plasmodium will die due to not being able to regenerate.

\section{Conclusion}

In conclusion, based on experimental results, this study succeeded in getting the three best compounds from Borassus flabellifer, Michelia figo and Cassia siamea which have a great potential activity to inhibit histo-aspartic protease. The highest affinity was shown by AM50 compounds, while the interaction of hydrogen resembled the original ligand, bound by the amino acid TRP - 39 showed in AM202 compounds. Thus, these three compounds can be an alternative to get potential antimalarial candidates from medicinal plants. Also, it is necessary to do both in vitro and in vivo tests to prove the HAP inhibition activity of the three candidate compounds on Plasmodium falciparum.

\section{Acknowledgment}

DMR thanks to University of Jember for research support

\section{References}

Badan Penelitian dan Pengembangan Kesehatan. (1997). Inventaris Tanaman Obat Indonesia IV. Jakarta: Departemen Kesehatan RI Badan Penelitian dan Pengembangan Kesehatan. (2006). Inventaris Tanaman Obat Indonesia VI. Jakarta: Departemen Kesehatan RI.

Banerjee, R., Liu, J., Beatty, W., Pelosof, L., Klemba, M., \& Goldberg, D. E. (2002). Four plasmepsins are active in the Plasmodium falciparum food vacuole, including a protease with an active-site histidine. Procedings of the National Academy of Sciences, 99(2), 990995.

Barelier, S., Sterling, T. O., Meara, M. J., \& Shoichet, B. K. (2015). The recognition of identical ligands by unrelated proteins. ACS Chemical Biology, 10(12), 2772-2784.

Bhaumik, P., Xiao, H., Parr, C. L., eKiso, Y., Gustchina, A., Yada, R. Y., \& Wlodawer. (2009). Crystal structures of the histo-aspartic protease (HAP) from Plasmodium falciparum. Journal of Molecular Biology, 388(3), 520-540. doi: 10.1016/j.jmb.2009.03.011

Coombs, G. H., Goldberg, D. E., Klemba, M., Berry, C., Kay, J., \& Mottram, J. C. (2011). Aspartic proteases of Plasmodium falciparum and other parasitic protozoa as drug targets. Trends in Parasitology, 17(11), 532-537.

Ersmark, K., Samuelsson, B., \& Hallberg, A. (2006). Plasmepsins as potential targets for new antimalarial therapy. Medical Research Reviews, 26(5), 626-666.

Esposito, A., Tiffert, T., Mauritz, J. M. A., Schlachter, S., Bannister, L. H., Kaminski, C. F., \& Lew, V. L. (2008). FRET imaging of hemoglobin concentration in Plasmodium falciparum-infected red cells. PLoS One, 3(11), e3780.

Gaspersz, N., \& Sohilait, M. R. (2019). Penambatan Molekuler $\alpha$, $\beta$, dan $\gamma$-mangostin Sebagai Inhibitor $\alpha$-amilase Pankreas Manusia. Indonesian Journal of Chemical Research, 6(2), 59-66.

Gething, P. W., Patil, A. P., Smith, D. L., Guerra, C. A., Elyazar, I. R. F., Johnston, L. G., Tatem, A. J., \& Hay, S. I. (2011). A new world malaria map: Plasmodium falciparum endemicity in 2010. Malaria Journal, 10(378), 1-16.

Guiguemde, T. R., Aouba, A., Ouedraogo, J. B., \& Lamizana, L. (1994). Ten-year surveillance of drug-resistant malaria in Burkina Faso (1982--1991). American Journal of Tropical Medicine and Hygiene, 50(6), 699-704.

Irawanto, R. (2011). Koleksi Palem yang Berpotensi Pangan dan Obat di Kebun Raya Purwodadi. 
Kolakovich, K. A., Gluzman, I. Y., Duffin, K. L., \& Goldberg, D. E. (1997). Generation of hemoglobin peptides in the acidic digestive vacuole of Plasmodium falciparum implicates peptide transport in amino acid production. Molecular and Biochemical Parasitology, 87(2), 123-135.

Lailaty, I. Q., Muhaimin, M., Handayani, A., Nadhifah, A., \& Noviady, I. (2016). Potential of Cibodas Botanic Gardens Plant Collection as the Future of Antimalarial Medicine, 9(1), 37-57.

Malau, N. D., \& Azzahra, S. F. (2019). Analisa Docking Cyanidin 3, 5-di-(6-malonylglucoside) terhadap Reseptor Plasmodium falciparum Enoyl Acyl Carrier Protein Reductase (PfENR) sebagai Anti Malaria. EduMatSains: Jurnal Pendidikan, Matematika dan Sains, 4(1), 99-110.

Müller, O., Traoré, C., \& Kouyaté, B. (2003). Clinical efficacy of chloroquine in young children with uncomplicated falciparum malaria-a community-based study in rural Burkina Faso. Tropical Medicine \& International Health, 8(3), 202-203.

Nelson, D. L., Lehninger, A. L., \& Cox, M. M. (2008). Lehninger Principles of Biochemistry. Macmillan

Nugraha, A. S., \& Keller, P. A. (2011). Revealing indigenous Indonesian traditional medicine: anti-infective agents. Natural Product Communications.,6(12), 1934578X1100601240.

Petersen, I., Eastman, R., \& Lanzer, M. (2011). Drug-resistant malaria: Molecular mechanisms and implications for public health. FEBS Letter, 585(11), 1551-1562.

Pratiwi, P., Sumarsih, S., Arwati, H., Amalina, I., Fanani, M. Z., Utomo, E. P., Fitri, L. E., Nugraha, A. S., Lie, W., \& Pyne, S. G. (2014). Epicroomine and croomine from stemona tuberosa antimalarial drug for inhibiting dihydrofolate reductase (DHFR) activity and their molecular modeling. Journal.of Chemical and Pharmaceutical Research, 6, 544-8.

Purnomo, H. (2011). Kimia komputasi: molecular docking PLANTS.2011. Yogyakarta: Pustaka Pelajar.

Rollando, R., Notario, D., Eva, M., Aditya, M., \& Sitepu, R. (2017). Antimicrobial, antioxidant, and cytotoxic activities of endhopitic fungi Chaetomium sp. isolated from Phyllanthus niruri Linn: in vitro and in silico studies. The Journal of Pure and Applied Chemistry Research, 6(1), 64.

Suhud, F., Siswandono, \& Budiati, T. (2015). others. Synthesis and activity evaluation of a novel lead compound 1-benzyl-3-benzoylurea as antiproliferative agent. World Journal of Pharmaceutical Sciences, 3(2), 1-10.

Thomas, G. (2004). Fundamentals of Medicinal Chemistry. John Wiley \& Sons.

World Health Organization. (2014). World health Day 2014: Fact Sheet Malaria.

World Health Organization. (2017). World Malaria Report 2017. (Geneva, ed.). WHO Press.

Xiao, H., Tanaka, T., Ogawa, M., \& Yada, R. Y. (2007). Expression and enzymatic characterization of the soluble recombinant plasmepsin I from Plasmodium falciparum. Protein Engineering, Design and Selection, 20(12), 625-633. 